\title{
Fault plane solutions as related to known geological faults in and near India
}

\author{
A. N. TANDOx $(*)-$ H. N. SRMASTMA $(* *)$
}

Recoiverd on Foblutury l6th, 1975

\begin{abstract}
SUmary. - Based on the focal mechanism solutions of newly determined solutions, and other recent workers the correlation between one of the nodal planes and the geological faults has been diseussed for three regroms nimely Kashmir, Central Himalayas and northeast India including Assan. The variability between multiple solutions reported for some earthquakes and the limitations in the choies of the nodal plane from $P$ 'waye solutions have been brought out.

It is seen that no standard eriteria either on the basis of isoseismals or of aftershoeks can be used to distinguish the falult plane from the aluxiliary plane. It has been found that in ereneral there is grood agreement between one of the nodal planes and the geological faults in Kashonir and the central IIimalayas. In northeast India, the strike directions obtained from the mechanism solutions generally ange with the trends of the main thrusts but the dip direction for shoeks originating in the India-Burna border is gencrally in opposite direction than postulated by the geologists.
\end{abstract}

Ruasuxto. - Viene discussa, basandosi su soluzioni più o meno recenti del meceanismo focale, la correlazione fra uno dei piani nodali a le faglie geologiche relative a tre regioni, il Kashmir, l'Himalaya centrale e l'India nord-orientale. Assam compreso. Sono state messe in luec le diversita fra le molteplici soluzioni riportate per aleuni terremoti e le linitizioni nella secelta delle soluzioni del piano nodale oftenuto dalle onde $P$.

si vede come non possano essere usati criteri standard ne basandosi sulle isosisme ne sulle repliche, per distinguere il piano di faglia da quello alusiliario.

In gencrale è stato trovato che cè buon accordo frà uno dei piani nodali e le faglie geologiche nel Kashmir a nell Himalaya Centrale. Nel-

(*) B7/50, Safdarjung Enclave, Sow Delhi, India.

$\left({ }^{* *}\right)$ Scismological Division, Metcorological Onfee, Lodi Road, New Delhi 110003. India. 
India noud-orientale la direzione nelle stratifieazioni ottenuta dalle soluzioni del meceanismo, di solito concorta con lorientamento delle spinte principali, mentre la direzione di inclinazione per le seosse che hanno origine al confine fra l'India e Burma e generalmente in senso opposto a quella stakilita dai geologi.

\section{TYTRODICTION}

The concept of Plate Tertonies offer's a mified theory to explain satisfactorily such phenomenon as the sea floor sprealling, bending of Ocean Trenches, continental drift voleanie eruptions, earthquakes and their occurrence along specified belts. Aceording to this theory the surface of the earth can be divided into several distinct plates some of which are stationary while the others are moving. Earthquakes oceur near the boundary of these plates. There are usually four types of boundaries namely at the crest of the mid oceanic ridges: (1) where the motion is che to tensile stresses; (2) the underthrusting of oceanic plate below the continent type plate into the mantle, such as in oceanic trenches; (3) boundaries along which the two plates move horizontally causing a "strilie slip" motion, as along the San Andreas Fault in California; (4) boundaries along which two eontinental type plate collide as in the case of the Indian plate and the Asian plate. In a oceanic-continental type collision earthquakes are distributed along a narrow belt while in the case of a continent-continent collision they oceur along a wicle zone.

In order to study the type of motion which oceurs along these plate boundaries focal mechanism solutions of earthquakes provide very valuable information. In addition to the faults located near the bounlary of global plates, many other faults are located within the plates themselves. Correlation of these local geological faults with the observed fault plane solutions is of significance from the point of view of regional tectonies.

The object of this paper is to discuss the fault plane solutions of earthquakes in and near India in relation to the observed fault parameter's. The discussion is based on 10 newly determined focal meehanism solutions from the $P$-wave first motion data whose details will be published elsewhere. In addition, we have included the solutions of Tohikawa et al. (1972) $\left({ }^{12}\right)$ whose results were earlier interpreted only with reference to the main boundary faults along the foothills of Himalayas. Ichikawa et al. (1972) (12) sumised that "focal mechenisms 
for such smaller earthquakes as used in the present study change often systematically from zone to zone in comnection with local geolog!y".

\section{Tamithtoxs of Fochl Mechaxisu Soletions}

Before discussing the correlation between focal mechanism solutions and geological faults it may be worthwhile to examine the uncertainties inherent in such solutions. Very often a number of solutions are obtained for the same earthquake due to shorteomings in the data. Even after obtaining a good solution it is not possible to say with certainty as to which of the two nodal planes obtained in the solution represents the fault plane. Table 1 gives a list of such earthquakes occurring in India and the different solutions obtained by varions workers. It will be seen that for earthquakes originating near the Nepal India border and those originating in the Foyna region (Maharashtra) the solutions differ rather widely. In some rases, for example the Koyna earthquake, there is a difference of opinion even in the nature of faulting which ranges from strike slip to dip slip. In the case of intermediate depth earthquakes such as those occurring in the Inindukush, the agreement between the solutions of various workers is much better. The diserepancies observed may be due to a number of anses, such as the use of data obtained only from pub)lished bulletins withont consulting the original reconds or inclusion of doubtful first arrivals (weak) from long period records. The use of data obtained from distant observatories for shocks of magnitude less than 5.5, may also lead to unreliable solutions particularly becanse of lower magnification of long period seismographs. In this connection, Nowroori (1972) $\left.{ }^{16}\right)$ discussed the affect of arustal velocities on earthquake mechanism solutions since they influence the angle between the downward vertical and the seismic ray at the soure. He found that the uncertainties of the crustal parameters have little alfect on solutions which have a prefominance of strike slip motion on a steeply dipping fault. The differences in the arustal velocities have however, significant effect for near stations and thus ronsiderably influence the solutions which have a component of dip slip movement. These considerations have a special significance for earthquakes oc:emring in the foothills of the Himalayas where regional variations in velocities exist and dip slip mechanism may be predominant. 
Table 1 - Multiple solutions of some Eartiquakes iN AND NeAR INdia.



SS: Strike slip

DS: Dip slip 


\section{CHOICE OF NoDAL Planies}

As pointed out earlier, each mechanism solution gives a choice of two nodal planes either of which may represent the fault plane. It is not possible to find out from observational data alone as to which of the solutions represents the fanlt plane. Different workers have used various eriteria for shoosing the correct solution, the most common being the consideration based on the local tectonic features. In arldition to these, some workers have used the trends in isoseismals, epicentral parameters of the aftershocks and the orientation of observed gromul fissures. Only in very rare rases surface faulting has been observed during an earthquake. In the (ase of San Fernandos earthquake of 1971 , Whitcomb et al. (1973) (32) found that there was a close correspondence between the fault plane, the hypocentral locations of aftershocks and regional geology. The ariteria nsed for some of the important Indian earthquakes is discussed below. The isoseismals for these earthquakes are shown in figure 1.

\subsection{Great Assum Earthqualie 19:50.}

The isoseismals of the great Assam Earthquake being elongated in a general east west direction and their tendency to come close together south of the epicentral tract in comparison to north enabled Tamblon (1955) (25) to choose the first norlal plane as the fault plane in agreement with the trend of geologieal faults. Tanclon (1954) (2-4) also determined the parameters of several of its aftershocks but due to the widespreal aftershock activity involving many thrusts/faults, the fault plane could not be chosen on this criteria.

\subsection{Burlyam eathquake 1960.}

The fault plane solution of Ichikawa et al. (1972) (12) shows that the norlal plane striking northwest-southeast dipping towards north-east. ahosen on the basis of Panjal thrust represents the applopriate fault plane. The isoseismals of this earthquake being oriented north-south (Srivastava et al. 1964) $\left({ }^{20}\right)$ do not fit with the fault plane solution.

\subsection{Anaruag earthqualie 196r.}

On the basis of precise determination of the aftershock parameters, Tandon (1972) ${ }^{(26)}$ fomml that the nodal plane dipping to sW 
indicates the fault plane which was not in conformity with the Panjal thrust dipping to north-east.

\subsection{Koyma rerthqualie 196\%.}

In Koyna region where detailed geological information is not yet available, Gupha et al. (1969) $\left(^{9}\right)$ chose the fault plane on the basis of isoseismals. Most of the other solutions giving ENE-WSW striking left lateral strike slip fault plane are supported by the aftershock data.

\subsection{Bhadrachalam pathquater 1969!.}

Based on the trend of the isoseismals Chaudhury et al. (1970)(') considered the solution which gave a fault striking east-north-east as the correct one. This also agreed with the trend of the Eastern Ghats. On the contrary (iupta et al. (1969) $\left({ }^{9}\right)$ have chosen the noral plane trending north-west on the basis of aftershockis.

\subsection{Broach earthqualie $19 \% 0$.}

For this earthquake (iupta et al. (1972)(10) have adopted a different criteria namely that of the trend of isoseismals and gromul fissures for choosing the fault plane. The chosen solution agreed with the general cast-east strike of the Narbada fault. Since no observatory existed rlose to the epicentre, aftershock data was not avalable. In this case Arora ef al. (1971) $\left.{ }^{1}\right)$ have however chosen a solution agreeing with the north-east trend of the Aravalli langes.

The above discussion thus indicates that no standard criteria either on the basis of aftershocks or isoseismals can be adopted for choosing the fault plane from $P$-wave analysis for earthquakes occurring in India.

It. may be interesting to mention that Green and Mc (aarr (1972) ( $\left.{ }^{8}\right)$ have also reported significant differences between the plane of faulting inlerred from the aftershock zone and that inferred from the lirst motion analysis for the Ceres earthquake of September 1969 in south Africa. They inferred that the aftershock distributions do not necessarily define earthquake faults even though they may define a plane. From the sturly of the Salinas Watsonvilla California earthqualie of 1963, Udias (1969) $(30)$ also observed that, the aftershocks were spreal along the direction of the axis of pressure insteal of along the direction of practure. 

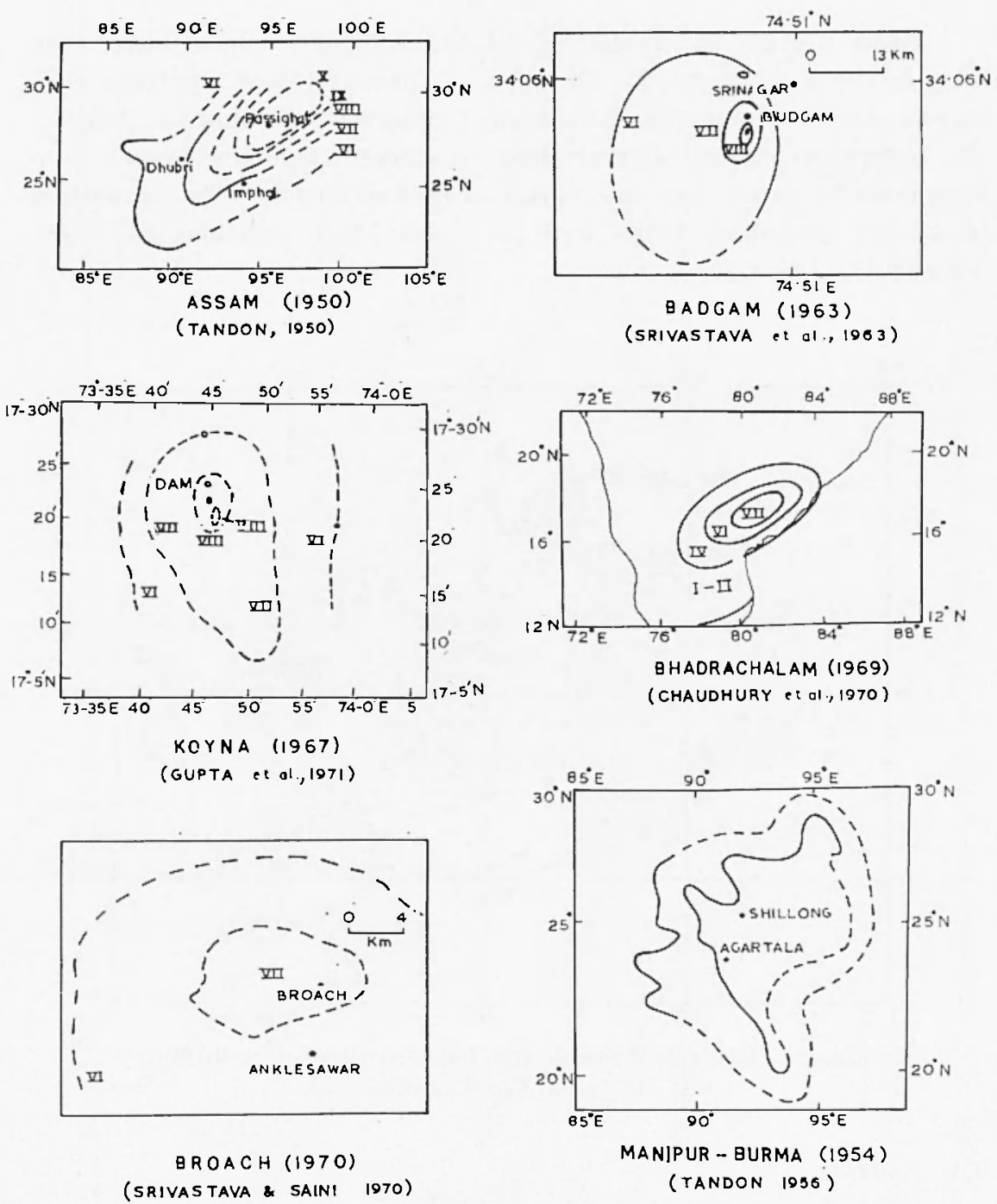

Isoseismals of some Earthquakes (on M-M Scale)

Fig. I -.. Isosetimmals of Inclian earthequakes. 


\section{FoCAL MECHANISA SOLLTIONS AXI) GEOLOGICAL FAUL'S}

Table 2 gives the results of all the solutions which have been used in the present sturly. In order to correlate these solutions with known faults along the Himalayan mountains (inclurding Assam), the epicentres of the earthquakes considered and the known geological faults in the area are shown in figures 2 to t. The correlation of known geological faults and the fault plane solutions for these regrions are discussed below.

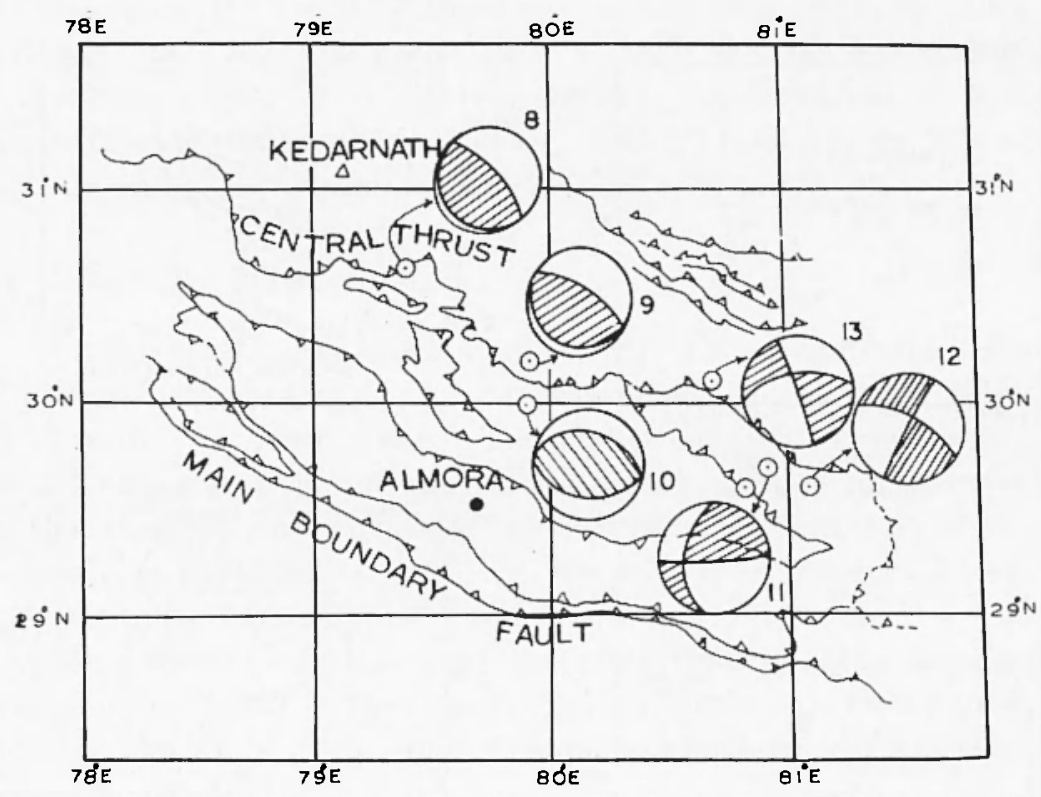

Fig. 2 - Geological faults and focal mechanisu solutions in India-Nepal border.

\subsection{Ladulih.}

The Ladakh-Karakorum belt is wedged between the Pamir block and the Spiti-Kashmir Tethyan belt with a suture zone along the Indus. According to Gansser (1973), ( $\left.{ }^{7}\right)$ the northern edge of the Indian plate coincides with the suture line. Event 1 occurred in Ladakh where due to poor geological information it is difficulti to correlate this event, with any known fanlt. 


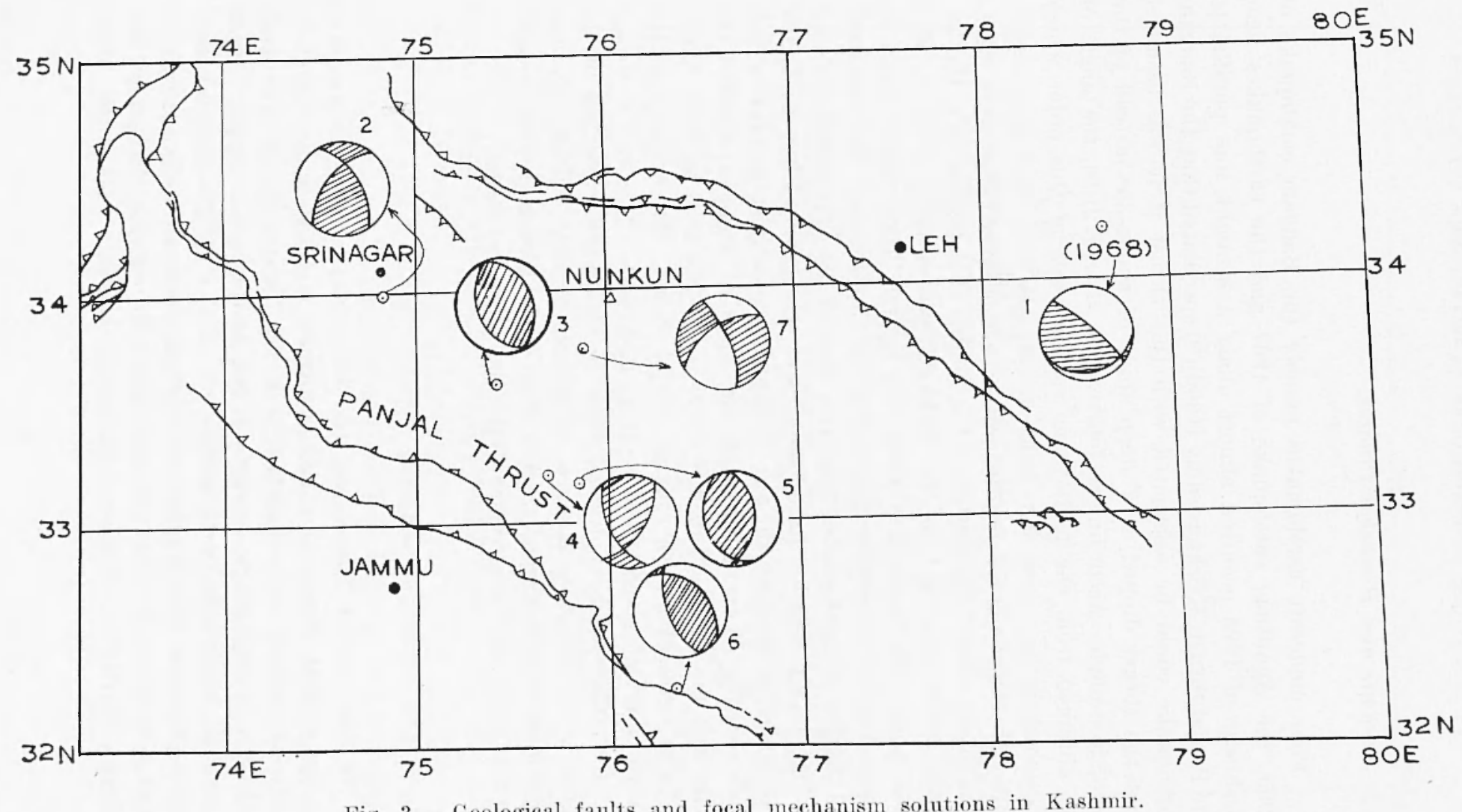

Fig. 3 - Geological faults and focal mechanism solutions in Kashmir. 


\subsection{Kashmir and Himachal Pradesh.}

Four moderate earthquakes namely the Bargam earthquake of 1963, the Anantnag earthquake of 1967 and the earthquakes near Kishtwar of 1973 oceured almost along a straight line parallel to the Panjal thrust. Krishmaswamy $(1966)\left({ }^{14}\right)$ speculated that the Badgam ardhquake could be associated with this thrust if it was assumed that the thrust dipped at a steep angle of about $35^{\text {o }}$ insteal of the usual low angle. Aceording to Ichikawa et al. (1972) $\left({ }^{12}\right)$, the angle of dip obtained from the fault plane solution was of this order which may confirm the association of this earthquake with the Panjal thrust. Although the computed faulting was of the thrust type it gave a predominantly strike slip motion. It is known that in Kashmir, the Tethyan rocks supported by the Salkhales are actually involved in a large horizontal translation along the Panjal thrust which could be responsible for the predominanee of strike slip motion. The Anantmag and Kishtwar earthquakes, however, showed dip slip thrust faulting. No agrement between focal mechanism solution and any geological fault could be found for the two earthquakes near Kishtwar. The fault plane solution of event about $50 \mathrm{~km}$ north of Kishtwal showed the strike and dip direction of one nodal plane (assumed as fault plane) to be in agreement with that of Panjal thrust, but in this case the nature of faulting conformed to a normal fault.

Event 6 with its epicentre colose to Dharamsala oceured in the region where the great Kangra earthquake of 1905 eaused huge destruetion of life and property. One of the nodal planes dipping towards the northeast was in agreement with the greological faults.

\subsection{Central II imalayses including Nepal.}

In the central Himalayas, the important geotectonic features are the central thrust, the Amora thrust, and the main boundary fault. Aceording to geologists, the north Almora thrust dips at a moderate to high angle towards south and trends west-north-west. in general, bending to north-north-west. The structural surface joins with the Srinagar fault further westward in Garhwal Valdiya (1973) (31) found a number of transvelse tear faults throughout the Lesser Himalayan Territory. Figure $t$ shows the epicentes of earhquakes 


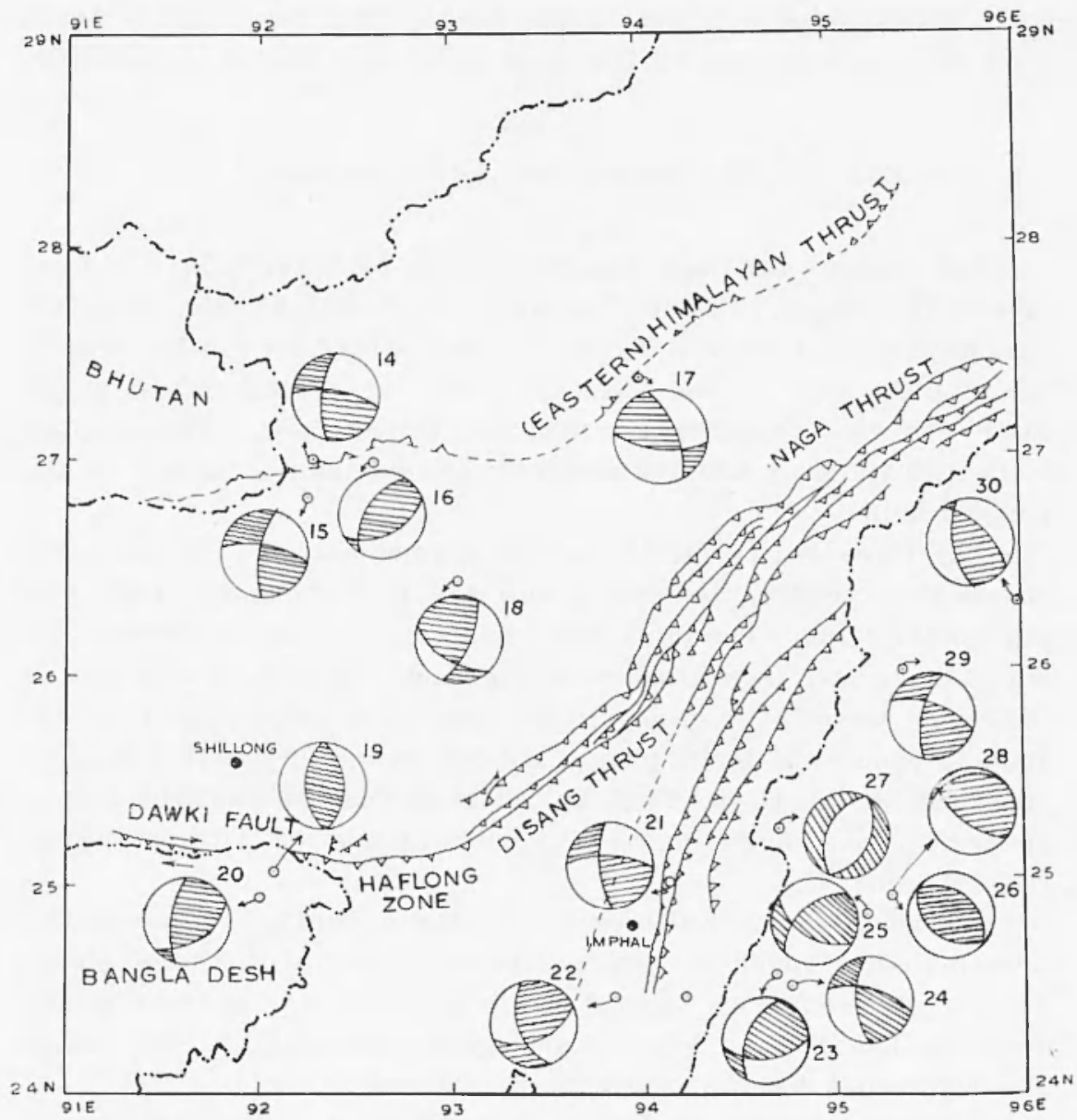

Fig. 4 - Geological fanlts and focal mechanism solutions in northeast India.

for which mechanism solutions are griven in table 2 , and the faults in the region.

The focal mechanism solutions of events 8 and 9 gave one nodal plane striking north-north-west in agreement with the strike of known faults. Fvent 10 which caused severe damage near Kapkote was located in between the two faults dipping in opposite directions. Considering the errors in the epicentral determination of this earthquake, the fault plane dipping towards north fits well with the geological faults. Event 11 indicated thrusting but none of the nodal planes 
conld be associated with the legronal fanlts. Such agreement is rathel groorl for events 12 and 13 but, large strike slip motion is indicated.

\subsection{Northerest India indurling Manipur-Burma region.}

Fig. 5) shows the main tectonic featmes of Assam along the foothills of Himalayas. Besilles the main boundary fault, the other important tectonic feature is the Dawki fanlt where the motion is right lateral strike slip. In the Naga hils, there are several thrusts whose soulh westiward extension is alled the Disang fault. The junction of the Dawki fault and northeasterly Disang fault is known as the Ilaflomgramit.

The three events 14, 15 and 16 showed that one of the noral planes were possibly associated with the main bomblary fault and showerl thrusting. The fant plane solution of event. 17 however did not indicate any correlation with this fault. Event 18 occurred in the region where litte geological information is known and thus difficult. to choose the faults plane. levents 19 and 20 oceurrerl in close proximity to the Dawki fault. but their meehanism solutions gave a northerly strike suggesting their possible association with the nealeel Ilaflomg zone.

Events 21 and 22 which oremured close to Manipur Burma thrusts showed that, although the strike direction of one of the norlal planes was in agreement with them, the dip direretion was in the opposite direcelion than derluced from the geological considerations. This lesult. also holds good for the events 23, 24, 25 and 29.

Mthough detailed geological information is laceking in Burma, the strike direction inferres from the fault plane solutions for the avents 26,26 and 30 ro not agree with the Manipur Burma thrusts. While most of the solutions in the region indieate thrusting with significant strike slip motion, the normal faulting for the event 2 in and the reverse dip direction for the earthquakes near Manipur-Burma border neesls further investignations.

It. may therefore, be summarised that the correlation between the fault plane solutions and known geological faults is generally good for earthquakes ocemring in Kashmir and along the foothills of Ilimalayas but fails for Manipur-Burma region where the faults are fomm to be dipping in the opposite direction than what has been dealuced by the geologists. 


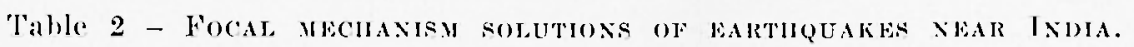

\begin{tabular}{|c|c|c|c|c|c|c|c|c|c|c|c|c|c|c|c|c|}
\hline \multirow{2}{*}{ So. } & \multirow{2}{*}{ Regrion } & \multirow{2}{*}{ Date } & \multicolumn{2}{|c|}{ Epicentre } & \multicolumn{3}{|c|}{ Origin time } & \multirow{2}{*}{$\begin{array}{c}D(p, t h \\
(\mathrm{km})\end{array}$} & \multirow{2}{*}{$\begin{array}{l}\text { Magni: } \\
\text { tude }\end{array}$} & \multirow{2}{*}{\multicolumn{3}{|c|}{$\begin{array}{c}\text { Nodal Plane I } \\
\text { Strike Dip Dip } \\
\text { Dir Mn } \\
\text { (dlegr.) }\end{array}$}} & \multirow{2}{*}{\multicolumn{2}{|c|}{$\begin{array}{c}\text { Nodal Plane } 2 \\
\text { Strike Dip Dip } \\
\text { Dir Dn } \\
\text { (dler.) }\end{array}$}} & \multirow{2}{*}{ Fanlt type } & \multirow{2}{*}{ Reforence } \\
\hline & & & 0. & of & l.. & m. & s. & & & & & & & & & \\
\hline \multirow[t]{2}{*}{1} & 2 & 3 & & & & 5 & & 6 & 7 & & 8 & & 9 & & 10 & 11 \\
\hline & Ladalih & & & & & & & & & & & & & & & \\
\hline \multirow[t]{2}{*}{1} & 一 & 11.2 .65 & $3+.2$ & 78.7 & 20 & 38 & 27 & 24 & 5.1 & $31+$ & +4 & 80 & 270180 & 15 & Thrust & Present study \\
\hline & Kashmir & & & & & & & & & & & & & & & \\
\hline 2 & Badgan & 2.9 .63 & 34.0 & 74.8 & 01 & 34 & 32 & $4+$ & 5.1 & 331 & 61 & 50 & $0+1311$ & 60 & Thrust & T(chikal wa et al. $(1972)\left({ }^{2}\right)$ \\
\hline 3 & Anantnag & 20.2 .67 & 33.6 & 75.4 & 15 & 18 & 40 & 25 & 5.7 & 330 & 66 & 33 & $3302+0$ & 57 & $\begin{array}{l}\text { 'Thrust, } \\
\text { Dip'slip }\end{array}$ & Tandon $(1972)(-6)$ \\
\hline 4 & Near Kishtwar & 16.1 .73 & 33.2 & 75.7 & 21 & 31 & 26 & +2 & 5.5 & 0.30 & 120 & 66 & $3+2 \quad 252$ & 45 & Thurust & $\begin{array}{c}\text { Chandhury of al. } \\
(197+)\left(i^{4}\right)\end{array}$ \\
\hline 5 & Noar Kishtwar & 24.10 .73 & 33.1 & 75.9 & 05 & 23 & 51 & 33 & 5.4 & 001 & 091 & 54 & 346256 & 34 & Thrust & Present study \\
\hline 6 & Near Dharamsala & 5.11 .68 & 32.3 & 76.5 & 02 & 02 & 45 & 33 & 4.9 & 328 & 1168 & 35 & 338248 & 67 & $\begin{array}{l}\text { Thrust, } \\
\text { Dip slip }\end{array}$ & $\begin{array}{l}\text { Chanulhury ot al. } \\
(197+)\left({ }^{4}\right)\end{array}$ \\
\hline \multirow[t]{2}{*}{7} & - & 17.6 .62 & 33.8 & 75.9 & 04 & 39 & 26 & 22 & 5.1 & 335 & 065 & 89 & $064 \quad 334$ & (j) & Normal & lehikawa ef al. $(1972)\left({ }^{12}\right)$ \\
\hline & Sepal India border & & & & & & & & & & & & & & & \\
\hline 8 & - & 22.6 .69 & 30.6 & 79.4 & 01 & 33 & 24 & 19 & 5.4 & 318 & 048 & 72 & 335246 & 20 & $\begin{array}{l}\text { Thrust, } \\
\text { Dip slip' }\end{array}$ & $\begin{array}{c}\text { ('handhury of al. } \\
(1974)(j)\end{array}$ \\
\hline 9 & - & 3.3 .69 & 30.2 & 79.9 & 06 & 20 & 22 & 18 & 5.3 & 320 & 0.50 & 32 & $298 \quad 208$ & 22 & $\begin{array}{l}\text { 'Thrust, } \\
\text { Dip' slip' }\end{array}$ & Srivastava $(1973)\left({ }^{19}\right)$ \\
\hline 10 & Kappoto & 28.12 .58 & 30.0 & 79.8 & 05 & 34 & +2 & 30 & 6.2 & 282 & 012 & 36 & $282 \quad 192$ & - . & $\begin{array}{l}\text { Thrust, } \\
\text { Dip slip }\end{array}$ & Present study \\
\hline 11 & - & 27.6 .66 & 29.7 & 80.9 & 10 & 59 & 18 & 33 & (i.0) & 270 & 180 & 80 & 010280 & 40 & Thrust & Ichikawa ot al. $(1972)\left({ }^{12}\right)$ \\
\hline \multirow[t]{2}{*}{12} & - & 2.12 .64 & 29.6 & 81.1 & 08 & 21 & 43 & 23 & 5.1 & 300 & 030 & 70 & 030300 & 90 & $\begin{array}{l}\text { Vertical, } \\
\text { strike slip) }\end{array}$ & Ichikawa et al. $(1972)\left({ }^{12}\right)$ \\
\hline & Northeast India & & & & & & & & & & & & & & & \\
\hline 13 & - & 26.9 .64 & 30.1 & 80.7 & 00 & 46 & 30 & 50 & 6.2 2 & $3+1$ & 171 & 89 & $0703+0$ & 60 & $\begin{array}{l}\text { Normal, } \\
\quad \text { Strike slip }\end{array}$ & Ichikawa of al. $(1972)\left({ }^{12}\right)$ \\
\hline 14 & 一 & 10.9 .64 & 27.1 & 92.3 & 13 & 22 & 10 & 33 & 5.6 & 231 & 1116 & 80 & 012282 & 69 & 'Thrust, ss. & Ichikawa ot al. $(1972)\left({ }^{12}\right)$ \\
\hline 15 & - & 11.4 .65 & 26.8 & 02.3 & 22 & 33 & 6 & 70 & 5.1 & 284 & $111+$ & 79 & $01+234$ & 89 & Thrust. SA. & Ichikawa of al. $(1972)\left({ }^{12}\right)$ \\
\hline 16 & 一 & 30.6 .69 & 26.9 & 92.7 & 68 & 51 & 54 & 44 & 5.0 & 028 & 298 & 48 & 068158 & 50 & Thrust & Present study \\
\hline 17 & - & 19.2 .70 & 27.4 & 94.0 & 07 & 10 & 02 & 52 & 5.3 & 344 & 11701 & 050 & 283193 & 060 & 'Thrust & $\begin{array}{l}\text { Chatudhury et al. } \\
(197+)\left({ }^{(j)}\right)\end{array}$ \\
\hline 18 & - & 17.7 .71 & 26.4 & 93.2 & 15 & 00 & 56 & 52 & 5.4 & 020 & 110 & 84 & 307217 & 46 & Thrust & $\begin{array}{l}\text { Chatudhury ot al. } \\
(197+)\left({ }^{4}\right)\end{array}$ \\
\hline 19 & - & 21.6 .63 & 25.1 & 92.1 & 15 & 20 & 31 & 56 & 5.6 & 001 & 271 & 50 & 001091 & 40 & Thrust, DS & Ichikawa of al. $(1972)\left({ }^{12}\right)$ \\
\hline 20 & - & 12.6 .68 & 24.9 & 91.9 & 04 & 29 & 22 & $4+$ & 5.3 & 030 & 120 & 6i.5 & $32+234$ & 40 & Thrust & Present study \\
\hline 21 & - & 18.2 .65 & 25.0 & 94.2 & 04 & 26 & 35 & 36 & 5.4 & 360 & 270 & 70 & $082 \quad 172$ & 70 & Nomal, St & Iehikawa of al. $(1972)\left({ }^{12}\right)$ \\
\hline 22 & 一 & 1.7 .57 & 24.4 & 93.8 & 19 & 30 & 23 & 41 & 6.0 & $3+2$ & 252 & 69 & $88 \quad 352$ & 65 & Thrust, SS & Iehikawa cet al. $(1972)\left({ }^{12}\right)$ \\
\hline 23 & - & $1+.6 .61$ & 24.5 & 04.7 & 00 & 41 & 10 & 91 & 5.3 & 030 & 300 & 60 & 270181 & 51 & $\begin{array}{l}\text { Thrust, } \\
\text { Ambignous }\end{array}$ & Ichikawa of al. $(1972)\left({ }^{12}\right)$ \\
\hline 24 & - & 2.10 .66 & 24.4 & 94.8 & 04 & 31 & 49 & 75 & 4.9 & 007 & 277 & 54 & $29+021$ & 69 & Thrust, ss & Present study \\
\hline 25 & $\cdots$ & 22.3 .54 & 24.4 & 95.2 & 23 & +2 & 12 & 180 & 7.5 & 050 & $N W$ & (i) & $124 \leqslant 11$ & (j) & Thrust & $\begin{array}{l}\text { Tandom and Mukherjece } \\
(1056)(28)\end{array}$ \\
\hline 26 & - & 4.2 .611 & 24.9 & 95.3 & 08 & 51 & 49 & & 5.5 & 306 & $216:$ & 39 & 3060636 & $\pi 1$ & Thrust, Is & Ichikawa of al. $(1972)\left({ }^{12}\right)$ \\
\hline $2 \overline{7}$ & - & 29.12 .71 & 25.2 & 9.47 & 22 & 27 & 10 & 46 & 5.0 & 028 & 298 & (60) & 328058 & 50 & Normal & Present study \\
\hline 28 & - & 12.7 .64 & 24.9 & 95.3 & 30 & 15 & 59 & 152 & 5.5 & 318 & 288 & 76 & $0763+6$ & 45 & Thrust, ss & Present study \\
\hline 29 & - & 29.7 .70 & 26.1 & 95.4 & 10 & 16 & 25 & 59 & 6.0 & 017 & 2871 & 060 & $293 \quad 023$ & 77 & 'Thrust. ss & Ichikawa of al. (1972) $\left({ }^{12}\right)$ \\
\hline 30 & - & 29.8 .69 & $\mathbf{2}(\mathbf{i} .3$ & 96.1 & 10 & 02 & 50 & 72 & 5.0 & 003 & 273 & 56 & 3200.50 & 40 & 'Thrust & Present study \\
\hline
\end{tabular}


The above study brings ont the following results:

(1) - The relationship between strike and (lip of the geological known faults with that lerived from focal mechanism using $P$-wave data generally holds good along the foothills of Himalayas but fails near Manipur-Burma region where intermediate focus earthquakes oceur frequently.

(2) - No stambard criteria on the basis of isoseismals or aftershocks could be fomnl out for distinguishing the fault plane from the anxiliary plane in the mechanism solutions for Indian earthquakes.

\section{ACNOWLEDGISMENT}

The anthors are thankful to the Director General of Observatories for permission to publish the paper.

\section{REFLRLNCLS}


of Mareh 23, 1970. "Earthquake Notes", XLII, 17.

(2) Bavaliar, A. R., 1972. - Foeal mechanism of Iudian earhquales. "Bull. Scism. Soc. Am.", 62. pp. 603-608.

$\left({ }^{3}\right)$ CuAspra, U., 1971. - Combination of P and $s$ data for the determination of earthqualie focal mechanism. "Bull. Sisism. Soc. Am.", 76, 1655.


Seismolectonic imestigations of the Mimalayges. "Ilimalayan Cicology", IV, Delhi-7, pl. 481-491.

(5) Chauna, R. K. S., Sixin, J. and V. K. Srwastra seminar on Geolynamies of the IVimalayan. Region. March 5.8. "National (ieophysical Roscareh Institute," Hyderabad, India, 201 (Abstract only).

(6) FrTcn, T. .., 1970. - Earthquake mechanism in the Himalayan, Burmese and sudaman regions and continental tectomios in Central siat. ".. (icoplyys. Res.", 75. pp. 2(i9)9-27099.

(i) Gassser, A., 1964. - Geolog!y of the Himalayas. Interseionec Publishers. 


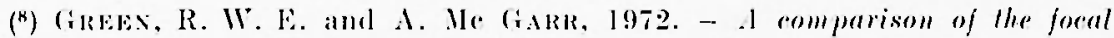
mechanism and aftershorli distribulion of the ceres, south . I frien earlhqualie of Seplember 29, 1969. "Bull. Suism. Soc. Am.", 62. pp. 869-871.


Sthedy of the Koyna parthquatie of Dee. 10, 1965. "Bull. Seism. Soc. 1m. . 59, pl. 1149-1162.

(10) (ivpta, H. K.. B. K. Rastocit, and H. NARas, 1972. - Amumal lieport. "Xational Geophysical Researeh Institute".

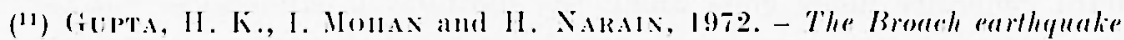
of .1/arch 2.3. 1970. "Bull. Seism, sioe, Am,", 62, pp. +7-61.

(12) Johkawa, .I., I. Х. Srivastava and J. Drakopoulos, 1972. - Foral mechanism of earlhquales oreurring in and around the Mimalayan and Burmese mounlecin bells. Pap. in "Iteteor. and Geophys.", 23. pp. 149-162.

(13) Kustrk1, K. X.. 1970. - The Koyna earlhquales seismir sludies. "Fourth symposium on Earthunake lingineer," Roorkee, pp. 369-374.

(11) KR1suxaswany, V. S., 1966. - Geo-seismological comsideralions relating to the planning and design of the salal hydel project and other lower Chenabcalleg hydel projects in ,Jammu and Kashmir slate. "Third symposium on Earthquake Enginecring". Roorkee, India, plp. 4+60.

(15) Lass, W. II. K. and ( . B. Ratiblatl, 1969. - Fanll plane solution of the Koyma (India) erallhualie. "Nature", 223, pp. 172-173.

(16) Nowrooz, A. A., 1972. - Focal mechamism of earthquaties in Persia, Turkey, Itest l'alistan, and Ifghanistan and plate tectoniess of the Middle liasl. "Bull. Neism. Sor. Am.", 62. pp. 823.850.

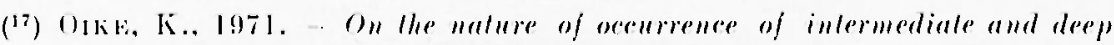
earlliqualies. The Itorld distribulion of the earlhqualie generating stress. "Bull. Disast. Preven. Res. Inst.", 20. It5.

$\left.{ }^{18}\right)$ Ritsivis, A. R., 1966. - The jaull-plane solutions of earthquales of the Limdulush Centre. "Tectonophysies", 3. pp. 147-163.

(19) SkIvastava. II. X., 1973. - The crustal seismicily and the malue of fanlling near India Tepal-Tibel trijunction. "Himalayan Geology", 3, pp. 321-393.

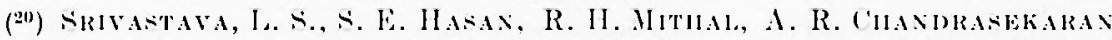
and Kk1suss, 1964. - Batgam rarthquale of sep. 2, 1963.3. "Bull. Ind. soc. Earth. Tech.", (India). 1. p). 79-94.

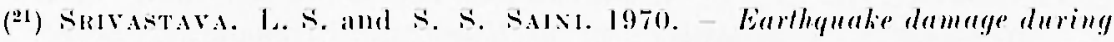

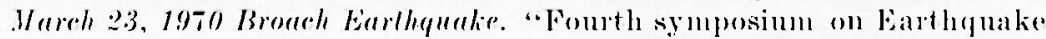
Engineering", 14-16, Nov. "school of Research and Training in Earthquake Engineering", Vniversity of Roorkere. Roorkere, India, pp. 25-43.

(22) SYkss. L. R.. 1970. - Seismicily of the Indian ocean and "possible nascent islamd are between Ceylon and I ustralin. "I. Geophys. Res." 75, pl). 5041. 5(1):5.).


and cullure, "Indian scienee Xews Association", 92. pp. 147-15is, lialcultil. Indial. 



19.50 and ils aflershocks. "Int. .I. of. Geophys.", 5, p1). 95-137.

(25) Taxion, A. X., 1955. - The direction of fantling in the great Assam earthqualie of 1:5 . Aug. 19.50. "Int. .J. Met. (ieophys.", 6. pp. 6il-64.

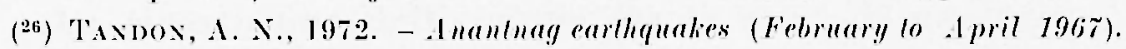
"Ind. I. Met. Geoplivs.", 23, pl. 491-502.


1965. "India Weteorologreal Department" "sceientific Report", 59.

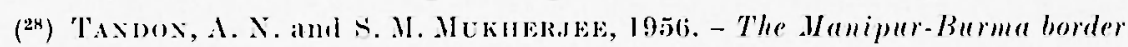
earthquale of 2.2 Jareh 19.j. "Ind. I. Met. Geophys.", 7, pp. 1-10.


(Abstract only). "Trans. Am. Geophys.".

$\left.{ }^{30}\right)$ LDIAs, A. S.I., 1965. - I study of the aflershocks and foctal mechanism of

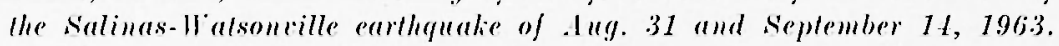
"Bull. Sicism. Soc. Atr.", 55, pl. 85-106.

(31) VALDYY. K. S., 1973. - Seminar on Geodynamies of the Himalayan region llareh .j-8, 1973. Published by "National Geophysical Researeh Institute. Ityderabad (Intia, 9).

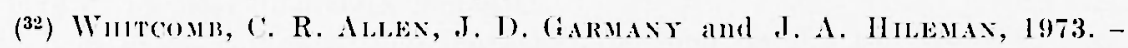
San Fermando Earthqualie Series, 1971: Focal mechanism and lectonics. "Reviews of Geophyises and space Physies", 11, Mp. 693-730. 